\title{
Intra Day Liquidity Facility Does it have an impact on Monetary Policy?
}

\author{
Dr. D.S. Wijesinghe*
}

\begin{abstract}
The Central Bank provides an intra day liquidity facility (ILF) free of charge to commercial banks and primary dealers to ensure smooth operations of the RTGS system. This paper examines whether the availability of ILF would have an impact on the conduct of monetary policy. It points out that, even before the introduction of the RTGS, intra day liquidity through the Central Bank was available in the form of an implicit intra day overdraft facility and hence, ILF would not have enhanced the liquidity available in the financial system. The paper observes no evidence in the settlement accounts of commercial banks and primary dealers at the Central Bank that the availability of ILF has enabled them to finance a higher volume of transactions. ILF is provided under stringent conditions with heavy penalties for defaults which ensures that the facility is not converted into an overnight credit. Accordingly, the release of funds under the ILF is unlikely to create an adverse impact on the conduct of monetary policy as funds flow back to the Central Bank on the same business day. (JEL E52 E58)
\end{abstract}

\section{Introduction}

In order to ensure smooth operations of the Real Time Gross Settlement (RTGS) system established in Sri Lanka on 8 September, 2003, the Central Bank of Sri Lanka provides an intra day liquidity facility (ILF) to its participating institutions, which are commercial banks and primary dealers in government securities. The facility is available free of charge against eligible securities. As the provision of ILF amounts to a release of funds by the Central Bank, one might presume that it would result in an enhancement in the volume of liquidity available in the financial system, and hence, would have an impact on the conduct of monetary policy. Therefore, a closer examination of the facility and its utilization by the participating institutions is warranted. Accordingly, this paper outlines the importance of intra day liquidity in a RTGS system, and the main features of the intra day liquidity facility

\footnotetext{
* The author wishes to thank Mrs. D.K. Mayadunna, Assistant Director, Domestic Operations Department of the Central Bank of Sri Lanka, for her assistance in the preparation of this paper.
} 
available in Sri Lanka and examines whether it would have an impact on the conduct of monetary policy.

\section{Importance of Intra day Liquidity in a RTGS System}

The most significant feature of a RTGS system is the settlement of a transaction as soon as the payment instruction is received by the system. Such immediate settlements, while important for time critical payments, eliminate the exposure of participants of a payment system to a risk of a payment being defaulted in a deferred in particular, end of day settlement system. In an end of day settlement system, if a participant defaults a payment, i.e. does not have sufficient funds to meet the payment, not only the recipient of the payment suffers a loss but it may also lead to a systemic impact on the system, as the recipient himself may become unable to honour his payment obligations. As the Central Bank may not wish to allow the payment system of the country to collapse, it would eventually be compelled to assume the risk of such defaults and loses arising out of them.

However, in order to reap the benefits of a RTGS system, its participants should have sufficient funds in their settlement accounts at the Central Bank at all time to meet their payment obligations. This is because, unlike in a differed settlement system, in a RTGS system in general, payments out of an account can not be netted off against receipts and an account is debited only if funds are available in the account to cover the payment in full. Otherwise, payments would be held up in queues without being settled. As payments and receipts are not always synchronized and one participant's payment is a receipt of another, the system could not be operated efficiently without liquidity being provided to finance payments until receipts are forthcoming during the course of a day. Hence, intra day liquidity is essential for smooth operations of a RTGS System.

A main source of intra day liquidity available for commercial banks in Sri Lanka is the balances maintained by them in their settlement accounts with the Central Bank in order to fulfill their obligations under the Statutory Reserve Requirement (SRR). Usually, balances under SRR are required to be maintained at the end of the day and hence, during the day, these balances could be utilized to meet intra day liquidity requirements. Normally, a large volume of intra day liquidity requirements of commercial banks is covered by SRR. However, when transactions of a bank is relatively large compared with its deposit base, the balance available under SRR may not be sufficient to meet its intra day liquidity requirement. Moreover, this source of intra day liquidity is not available to primary dealers as they are not subject to SRR. Therefore, it is essential that intra day liquidity is provided to the members of RTGS to ensure that it is operated smoothly.

\section{Salient Features of ILF}

In Sri Lanka, ILF is granted free of charge on request to commercial banks and primary dealers against eligible securities. At present, eligible securities are government Treasury bills and Treasury bonds. The participants who wish to obtain ILF at the beginning of the day is required to reposition, before the close of business on the previous business day, an adequate volume of eligible securities from their own accounts to their ILF accounts in the scripless securities settlement system, LankaSecure, which is an integral part of the RTGS system in Sri Lanka, which is code named, LankaSettle. During the business day also, participants could draw ILF at three designated times by repositioning eligible securities into their ILF accounts, after informing the Central Bank their wish to obtain ILF and the required amount. The Central Bank is prepared to accommodate requests for ILF even in between the designated times, if there happens to be an urgent requirement.

The provision of ILF is in the form of a repurchase agreement to repurchase by the participant the securities against which ILF is provided by repaying the outstanding ILF on or before the time specified for the repayment. Accordingly, the provision of ILF is governed by an ILF agreement between the Central Bank and each participating institution signed by the Monetary Board of the Central Bank and the Chief Executive Officer of each participating institution.

ILF is provided for the current market value, subject to a 'hair cut' as determined by the Central Bank, of the securities against which ILF is sought. The Central Bank daily updates, based on current market prices and taking into account market developments, a list of official prices of Treasury bills and Treasury bonds of each remaining days to maturity and records it in LankaSettle. The 'hair cuts', have been determined by studying daily variations in prices of these securities in the secondary market and are imposed to eliminate the exposure of the Central Bank to any losses in the value of securities it purchased due to variations in prices. In exceptional circumstances, the Central Bank has the right to revise the official prices during the business day and revalue the securities provided as collateral on the revised official prices. Participants may be required to make a replenishment of securities on the basis of such a revaluation.

Participants are not permitted to make substitutions for securities against which ILF is granted but are allowed to regain whole or a part of them before the specified time for the repayment by returning the funds borrowed under ILF fully or partially. Such reversals would be on a prior agreement with the Central Bank and allowed only once during each business day.

The process of reversal of ILF is initiated at a specified time and participants must ensure that funds are available in their settlement accounts to settle in full all outstanding ILF balances. Strong measures are in place to ensure that participants will settle their ILF 
balances on time. If a participant fails to settle in full the outstanding ILF balance, he will become liable to pay a default interest on the full amount. The default interest would be at a rate equivalent to the Bank Rate at the first occasion of such a default. On each successive occasion of defaults during a calendar year, default interest rate will be increased by 100 bps. The Bank Rate is a penal rate (at present 15 per cent) which is substantially higher than the reverse repurchase rate of the Central Bank (at present 12 per cent), the rate at which participants could borrow from the Central Bank on overnight basis. Accordingly, this default interest in fact is an effective deterrent to the overnight use of the intra day facility.

The defaults are further discouraged by imposing a condition that the Central Bank will retain the securities against which such funds were provided and deal with them in its own rights in an event if a participant fails to settle in full the amount in default before the end of business on the next business day. The securities will be retained in a similar manner if a participant defaults more than once in a month, in addition to charging default interests on the full amount. In the event of repeated defaults, the Central Bank may withdraw the availability of ILF to the participant for a period of time determined by the Central Bank. Notwithstanding any of these provisions, the Central Bank may at its sole discretion, taking into consideration the circumstances of a default, withdraw the availability of ILF to participant permanently or for a period of time determined by the Central Bank.

Accordingly, the terms and conditions against which ILF is granted ensure that the Central Bank is not exposed to a risk on account of the provision of ILF and ILF is not converted into an overnight credit.

\section{Impact of ILF on Liquidity Available in Financial System}

Under the end of day settlement system that existed before the introduction of RTGS, transactions among commercial banks and primary dealers were effected by Central Bank cheques drawn against their settlement accounts maintained at the Central Bank. These cheques were processed and settled at the end of the day. Under this system, banks and primary dealers could have made payments by issuing Central Bank cheques, even if they did not have sufficient funds in their settlement accounts at the time of effecting the payments. This implies that they were permitted to overdraw their accounts during the day and accordingly provided with intra day liquidity, implicitly without a limit and without any collateral. In other words, instead of ILF, under the end of day settlement system, there existed, an intra day overdraft facility implicitly provided by the Central Bank. Therefore, the provision of ILF under RTGS would not in principle have led to an increase in the overall liquidity in the financial system. In fact, overall liquidity might have been declined, as participants may economise on the use of ILF as it is available only against the eligible securities.
An estimate on the maximum level of ILF that could have been implicitly utilized by commercial banks and primary dealers could be made by comparing the opening balances in their settlement accounts with total debits and credits to the settlement accounts under certain assumptions. If it were assumed that all credits to accounts were at the end of the day, then they would have implicitly utilized ILF to cover the differences between total debits and the value of the opening balances. Alternatively, a more conservative estimate could be made by assuming that one half of the credits were made at the beginning of the day. These estimates have to be made for each institution, and not for the system as a whole in aggregate. An institution with an opening balance which is higher than total debits to its account would have not obtained ILF, and hence, at the aggregate level ILF requirements might not be observable. Accordingly, estimates were made only for the heavy users of ILF during the first two months of operations of RTGS (i.e., September and October 2003) and are shown in Table 1a and 1b. The estimates highlight the potential ILF requirements of these users of ILF and could be compared with their actual drawings of ILF during the first two months. These estimates provide evidence that in general ILF drawings during the first two months were substantially lower than the maximum intra day credit they might have obtained implicitly under the end of day settlement system.

\section{Monetary Policy Implications of ILF}

It was argued in the previous section that the overall liquidity under the RTGS system with ILF provided by the Central Bank could not in principle be higher than that existed under the end of day settlement system. If ILF under RTGS has had an expansionary impact, it should have enabled banks and primary dealers,

(a) to finance a larger volume of transactions as indicated by a larger volume of debits to their accounts and/or

(b) to maintain smaller working balances in their settlement accounts.

In Sri Lanka, $(b)$ is not possible for banks, as they have to maintain the Statutory Reserve Requirement in their settlement accounts, which at 10 per cent of deposit liabilities is likely to well exceed usual working balance requirements. Even before the introduction of RTGS primary dealers had maintained only small balances in their settlement accounts and it is hardly possible to reduce them further.

For major drawers of ILF, comparable data on their average as well as maximum and minimum opening balances, debits and credits to their accounts during pre-RTGS and post-RTGS periods together with the implicit ILF and during the post RTGS period, ILF drawings are shown in Table 1a and 1b. Data for one state bank (State Bank A), one foreign bank (Foreign Bank A) and two domestic private banks (Domestic Private Bank A an Domestic Private Bank B) which accounted for around 85 per cent of the ILF drawings 
Table 1a

Implicit ILF under End of Day Settlement and ILF Drawings under RTGS Selected Commercial Banks

\begin{tabular}{|c|c|c|c|c|c|c|c|}
\hline Period & Bank & $\begin{array}{l}\text { Opening } \\
\text { Balance } \\
\text { (1) }\end{array}$ & $\begin{array}{c}\text { Debits } \\
\text { (2) }\end{array}$ & $\begin{array}{c}\text { Credits } \\
\text { (3) }\end{array}$ & $\begin{array}{c}\text { ILF1 } \\
(4)=(2-1) \\
\text { If }>0\end{array}$ & $\begin{array}{c}\text { ILF2 } \\
(5)=2-(1+0.5 * 3) \\
\text { If }>0\end{array}$ & $\begin{array}{l}\text { ILF } \\
\text { Unde } \\
\text { RTGS }\end{array}$ \\
\hline \multirow{4}{*}{ July 03} & State Bank A & & & & & & \\
\hline & Avg. & 8,704 & 4,914 & 4,895 & 0 & 0 & \\
\hline & Min. & 8,262 & 2,883 & 4,753 & 0 & 0 & \\
\hline & Max. & 8,206 & 13,876 & 18,321 & 5,670 & 0 & \\
\hline \multirow[t]{3}{*}{ Aug 03} & Avg. & 8,585 & 5,368 & 5,409 & 0 & 0 & \\
\hline & Min. & 8,404 & 2,462 & 2,673 & 0 & 0 & \\
\hline & Max. & 7,466 & 16,435 & 18,399 & 8,969 & 0 & \\
\hline \multirow{3}{*}{$\begin{array}{l}\text { Sept. } 03 \\
(01-05)\end{array}$} & Avg. & 8,824 & 8,690 & 8,862 & 0 & 0 & \\
\hline & Min. & 8,067 & 6,104 & 6,262 & 0 & 0 & \\
\hline & Max. & 8,296 & 13,111 & 15,792 & 4,815 & 0 & \\
\hline \multicolumn{8}{|l|}{ Post-RTGS } \\
\hline \multirow{3}{*}{$\begin{array}{l}\text { Sept. } 03 \\
(08-30)\end{array}$} & Avg. & 8,184 & 6,703 & 6,700 & 0 & & 3,000 \\
\hline & Min. & 7,735 & 4,552 & 4,953 & 0 & & 3,000 \\
\hline & Max. & 8,907 & 11,182 & 100,094 & 2,275 & & 3,000 \\
\hline \multirow[t]{3}{*}{ Oct. 03} & Avg. & 8,392 & 6,209 & 6,114 & 0 & & 1,571 \\
\hline & Min. & 8,147 & 2,718 & 4,193 & 0 & & \\
\hline & Max. & 8,614 & 14,044 & 12,760 & 5,430 & & 3,000 \\
\hline \multirow{4}{*}{ July 03} & Foreign Bank $\mathrm{A}$ & & & & & & \\
\hline & Avg. & 1,317 & 4,908 & 4,118 & 2,781 & 722 & \\
\hline & Min. & 1,290 & 1,945 & 1,902 & 655 & 0 & \\
\hline & Max. & 1,581 & 8,331 & 7,925 & 6,750 & 2,788 & \\
\hline \multirow[t]{3}{*}{ Aug. 03} & Avg. & 1,371 & 2,174 & 2,156 & 803 & 0 & \\
\hline & Min. & 1,208 & 979 & 1,270 & 0 & 0 & \\
\hline & Max. & 1,366 & 3,983 & 3,843 & 2,617 & 696 & \\
\hline \multirow{3}{*}{$\begin{array}{l}\text { Sept. } 03 \\
(01-05)\end{array}$} & Avg. & 1,326 & 3,048 & 3,024 & 1,723 & 211 & \\
\hline & Min. & 1,226 & 2,634 & 2,867 & 1,408 & 0 & \\
\hline & Max. & 1,459 & 3,677 & 3,463 & 2,218 & 487 & \\
\hline \multicolumn{8}{|l|}{ Post-RTGS } \\
\hline \multirow{3}{*}{$\begin{array}{l}\text { Sept. } 03 \\
\text { (08-30 Sept.) }\end{array}$} & Avg. & 1,378 & 2,901 & 3,101 & 1,523 & & \\
\hline & Min. & 1,386 & 2,110 & 2,246 & 724 & & \\
\hline & Max. & 1,386 & 5,159 & 3,087 & 3,773 & & \\
\hline \multirow[t]{3}{*}{ Oct. 03} & Avg. & 1,378 & 2,919 & 2,843 & 1,541 & & \\
\hline & Min. & 1,203 & 1,037 & 1,030 & 0 & & \\
\hline & Max. & 1,305 & 6,320 & 3,419 & 5,015 & & \\
\hline
\end{tabular}

6

CENTRAL BANK OF SRI LANKA

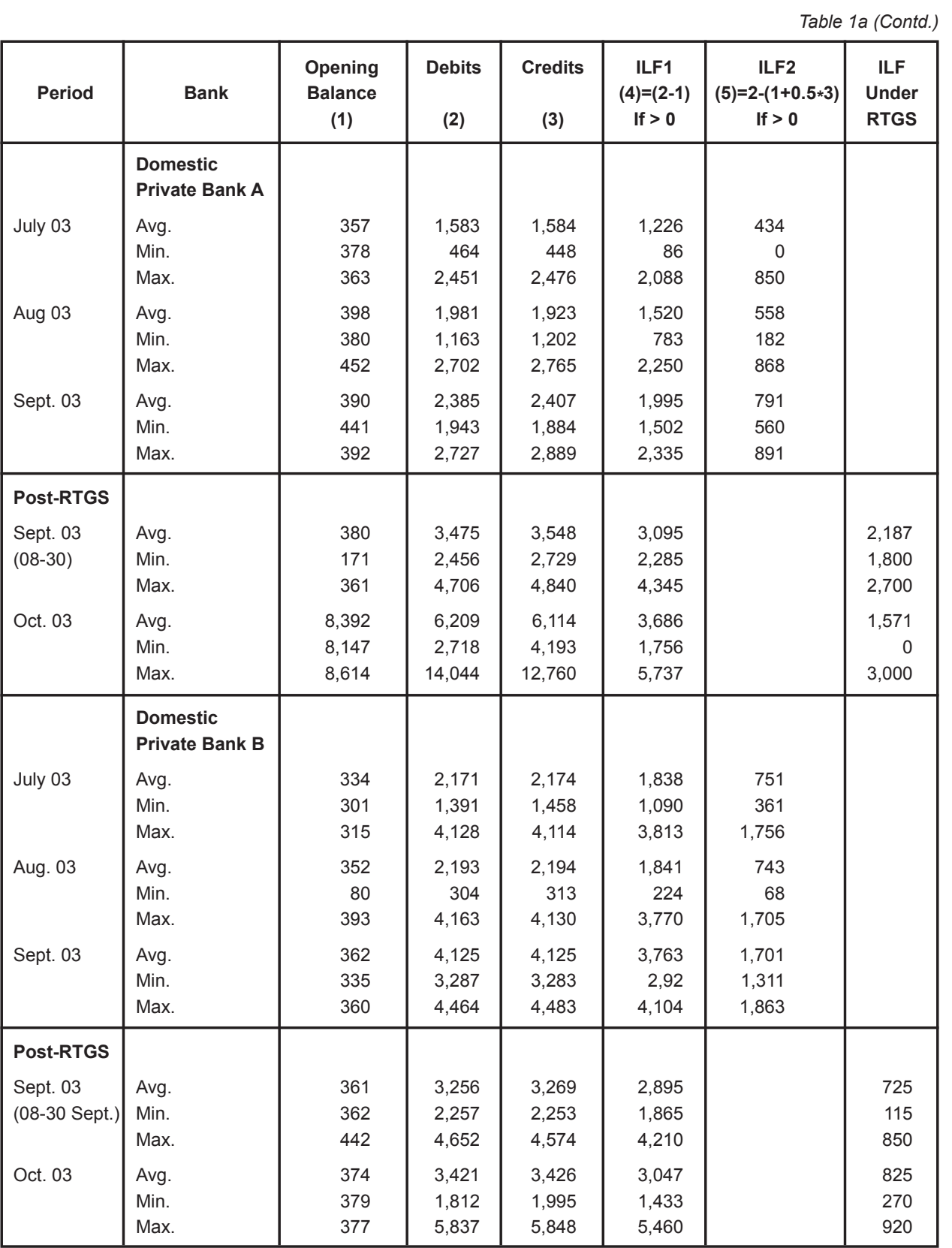

$I L F 1=$ Implicit ILF under the assumption that all credits were at the end of the day

$I L F 2=I m p l i c i t ~ I L F$ under the assumption that a half of credits were at the start of the day

Min. Max. refer to the minimum and maximum of debits during the month and corresponding opening balance and credit realized on the same day.

CENTRAL BANK OF SRI LANKA 
Table $1 b$

Implicit ILF under End of Day Settlement and ILF Drawings under RTGS Selected Primary Dealers

\begin{tabular}{|c|c|c|c|c|c|c|c|}
\hline Period & $\begin{array}{c}\text { Primary } \\
\text { Dealer }\end{array}$ & $\begin{array}{l}\text { Opening } \\
\text { Balance } \\
\text { (1) }\end{array}$ & $\begin{array}{c}\text { Debits } \\
\text { (2) }\end{array}$ & $\begin{array}{c}\text { Credits } \\
\text { (3) }\end{array}$ & $\begin{array}{c}\text { ILF1 } \\
(4)=(2-1) \\
\text { If }>0\end{array}$ & $\begin{array}{c}\text { ILF2 } \\
(5)=2-(1+0.5 * 3) \\
\text { If }>0\end{array}$ & $\begin{array}{l}\text { ILF } \\
\text { Unde } \\
\text { RTGS }\end{array}$ \\
\hline July 03 & $\begin{array}{l}\text { PD } 1 \\
\text { Avg. } \\
\text { Min. } \\
\text { Max. }\end{array}$ & $\begin{array}{l}2.5 \\
2.0 \\
2.0\end{array}$ & $\begin{array}{r}579 \\
189 \\
1,098\end{array}$ & $\begin{array}{r}579 \\
189 \\
1,097\end{array}$ & $\begin{array}{r}576 \\
187 \\
1,096\end{array}$ & $\begin{array}{r}287 \\
93 \\
548\end{array}$ & \\
\hline Aug 03 & $\begin{array}{l}\text { Avg. } \\
\text { Min. } \\
\text { Max. }\end{array}$ & $\begin{array}{l}1.2 \\
0.0 \\
2.0\end{array}$ & $\begin{array}{r}471 \\
32 \\
1,314\end{array}$ & $\begin{array}{r}471 \\
32 \\
1,314\end{array}$ & $\begin{array}{r}470 \\
32 \\
1,313\end{array}$ & $\begin{array}{r}235 \\
16 \\
656\end{array}$ & \\
\hline $\begin{array}{l}\text { Sept. } 03 \\
(01-05)\end{array}$ & $\begin{array}{l}\text { Avg. } \\
\text { Min. } \\
\text { Max. }\end{array}$ & $\begin{array}{l}1.4 \\
1.0 \\
2.0\end{array}$ & $\begin{array}{r}668 \\
287 \\
1,186\end{array}$ & $\begin{array}{r}668 \\
287 \\
1,185\end{array}$ & $\begin{array}{r}667 \\
286 \\
1,184\end{array}$ & $\begin{array}{l}333 \\
143 \\
592\end{array}$ & \\
\hline Post-RTGS & & & & & & & \\
\hline $\begin{array}{l}\text { Sept. } 03 \\
(08-30)\end{array}$ & $\begin{array}{l}\text { Avg. } \\
\text { Min. } \\
\text { Max. }\end{array}$ & $\begin{array}{l}1.3 \\
6.0 \\
0.0\end{array}$ & $\begin{array}{l}540 \\
205 \\
988\end{array}$ & $\begin{array}{l}540 \\
199 \\
990\end{array}$ & $\begin{array}{l}539 \\
199 \\
988\end{array}$ & & $\begin{array}{l}110 \\
110 \\
110\end{array}$ \\
\hline Oct. 03 & $\begin{array}{l}\text { Avg. } \\
\text { Min. } \\
\text { Max. }\end{array}$ & $\begin{array}{l}0.7 \\
0.0 \\
1.0\end{array}$ & $\begin{array}{l}391 \\
109 \\
927\end{array}$ & $\begin{array}{l}391 \\
110 \\
926\end{array}$ & $\begin{array}{l}390 \\
109 \\
926\end{array}$ & & $\begin{array}{l}110 \\
110 \\
110\end{array}$ \\
\hline July 03 & $\begin{array}{l}\text { PD } 2 \\
\text { Avg. } \\
\text { Min. } \\
\text { Max. }\end{array}$ & $\begin{array}{l}0.5 \\
0.0 \\
0.0\end{array}$ & $\begin{array}{r}1,032 \\
226 \\
2,217\end{array}$ & $\begin{array}{r}1,032 \\
226 \\
2,217\end{array}$ & $\begin{array}{r}1,032 \\
226 \\
2,217\end{array}$ & $\begin{array}{r}515 \\
113 \\
1,109\end{array}$ & \\
\hline Aug. 03 & $\begin{array}{l}\text { Avg. } \\
\text { Min. } \\
\text { Max. }\end{array}$ & $\begin{array}{l}1.3 \\
1.0 \\
1.0\end{array}$ & $\begin{array}{r}1,390 \\
257 \\
2,451\end{array}$ & $\begin{array}{r}1,390 \\
257 \\
2,451\end{array}$ & $\begin{array}{r}1,389 \\
256 \\
2,450\end{array}$ & $\begin{array}{r}694 \\
128 \\
1,225\end{array}$ & \\
\hline $\begin{array}{l}\text { Sept. } 03 \\
\text { (01-05) }\end{array}$ & $\begin{array}{l}\text { Avg. } \\
\text { Min. } \\
\text { Max. }\end{array}$ & $\begin{array}{l}1.0 \\
1.0 \\
0.0\end{array}$ & $\begin{array}{r}1,032 \\
479 \\
1,822\end{array}$ & $\begin{array}{r}1,035 \\
482 \\
1,823\end{array}$ & $\begin{array}{r}1,032 \\
478 \\
1,822\end{array}$ & $\begin{array}{l}515 \\
237 \\
911\end{array}$ & \\
\hline Post-RTGS & & & & & & & \\
\hline $\begin{array}{l}\text { Sept. } 03 \\
\text { (08-30 Sept.) }\end{array}$ & $\begin{array}{l}\text { Avg. } \\
\text { Min. } \\
\text { Max. }\end{array}$ & $\begin{array}{r}70.2 \\
14.0 \\
2.0\end{array}$ & $\begin{array}{r}1,409 \\
102 \\
3,499\end{array}$ & $\begin{array}{r}1,407 \\
90 \\
2,630\end{array}$ & $\begin{array}{r}1,339 \\
88 \\
3,497\end{array}$ & & $\begin{array}{r}551 \\
250 \\
1,120\end{array}$ \\
\hline Oct. 03 & $\begin{array}{l}\text { Avg. } \\
\text { Min. } \\
\text { Max. }\end{array}$ & $\begin{array}{l}2.8 \\
1.0 \\
9.0\end{array}$ & $\begin{array}{r}779 \\
366 \\
1,383\end{array}$ & $\begin{array}{r}779 \\
356 \\
1,377\end{array}$ & $\begin{array}{r}776 \\
354 \\
1,374\end{array}$ & & $\begin{array}{l}250 \\
250 \\
250\end{array}$ \\
\hline
\end{tabular}

\begin{tabular}{|c|c|c|c|c|c|c|c|}
\hline Period & Bank & $\begin{array}{l}\text { Opening } \\
\text { Balance } \\
\text { (1) }\end{array}$ & $\begin{array}{l}\text { Debits } \\
\text { (2) }\end{array}$ & $\begin{array}{l}\text { Credits } \\
\text { (3) }\end{array}$ & $\begin{array}{c}\text { ILF1 } \\
(4)=(2-1) \\
\text { If }>0\end{array}$ & $\begin{array}{c}\text { ILF2 } \\
\left(\begin{array}{l}(5)=2-(1+0.5 * 3) \\
\text { If }>0\end{array}\right.\end{array}$ & $\begin{array}{l}\text { ILF } \\
\text { Under } \\
\text { RTGS }\end{array}$ \\
\hline \multirow{4}{*}{ July 03} & PD 3 & & & & & & \\
\hline & Avg. & 6.0 & 1,070 & 1,070 & 1,064 & 529 & \\
\hline & Min. & 19.0 & 439 & 424 & 420 & 208 & \\
\hline & Max. & 25.0 & 2,487 & 2,482 & 2,462 & 1,221 & \\
\hline \multirow{3}{*}{ Aug 03} & Avg. & 2.0 & 811 & 811 & 809 & 404 & \\
\hline & Min. & 0.0 & 59 & 59 & 59 & 30 & \\
\hline & Max. & 0.0 & 2,330 & 233 & 2,330 & 1,165 & \\
\hline \multirow{3}{*}{$\begin{array}{l}\text { Sept. } 03 \\
\text { (01-05) }\end{array}$} & Avg. & 3.0 & 1,504 & 1,505 & 1,501 & 749 & \\
\hline & Min. & 0.0 & 668 & 680 & 668 & 328 & \\
\hline & Max. & 0.0 & 2,627 & 2,627 & 2,627 & 1,314 & \\
\hline \multicolumn{8}{|l|}{ Post-RTGS } \\
\hline \multirow{3}{*}{$\begin{array}{l}\text { Sept. } 03 \\
(08-30)\end{array}$} & Avg. & 13.5 & 1,155 & 1,160 & 1,142 & & 106 \\
\hline & Min. & 100.0 & 248 & 148 & 148 & & 130 \\
\hline & Max. & 0.0 & 2,045 & 2,221 & 2,045 & & 345 \\
\hline \multirow[t]{3}{*}{ Oct. 03} & Avg. & 0.3 & 639 & 640 & 639 & & 62 \\
\hline & Min. & 0.1 & 91 & 91 & 91 & & 100 \\
\hline & Max. & 0.7 & 1,870 & 1,970 & 1,869 & & 200 \\
\hline \multirow{4}{*}{ July 03} & PD 4 & & & & & & \\
\hline & Avg. & 4.0 & 449 & 450 & 445 & 220 & \\
\hline & Min. & 4.0 & 122 & 118 & 118 & 59 & \\
\hline & Max. & 2.0 & 743 & 761 & 741 & 361 & \\
\hline \multirow[t]{3}{*}{ Aug. 03} & Avg. & 1.0 & 471 & 471 & 470 & 235 & \\
\hline & Min. & 1.0 & 179 & 178 & 178 & 89 & \\
\hline & Max. & 1.0 & 913 & 913 & 912 & 456 & \\
\hline \multirow[t]{3}{*}{ Sept. 03} & Avg. & 5.0 & 473 & 473 & 468 & 232 & \\
\hline & Min. & 1.0 & 280 & 280 & 279 & 139 & \\
\hline & Max. & 19.0 & 709 & 691 & 690 & 345 & \\
\hline \multicolumn{8}{|l|}{ Post-RTGS } \\
\hline \multirow{3}{*}{$\begin{array}{l}\text { Sept. } 03 \\
\text { (08-30 Sept. }\end{array}$} & Avg. & 0.7 & 260 & 270 & 259 & & 116 \\
\hline & Min. & 0.0 & 22 & 73 & 22 & & 50 \\
\hline & Max. & 1.0 & 602 & 602 & 601 & & 205 \\
\hline \multirow[t]{3}{*}{ Oct. 03} & Avg. & 1.0 & 240 & 242 & 239 & & 154 \\
\hline & Min. & 0.3 & 0 & 0 & 0 & & 147 \\
\hline & Max. & 0.0 & 669 & 669 & 669 & & 155 \\
\hline
\end{tabular}

$I L F 1=$ Implicit ILF under the assumption that all credits were at the end of the day

$I L F 2=$ Implicit ILF under the assumption that a half of credits were at the start of the day

Min. Max. refer to the minimum and maximum of debits during the month and corresponding opening balance and credit realized on the same day. 
during the first two months are shown, together with comparable data for a few primary dealers (PD1, PD2 and PD3). The following observations were drawn from these data.

\section{(i) State Bank A}

State Bank A has drawn ILF amounting to Rs.3 billion on each business day until 16 October, 2003. However, except for a few days, total debits to its settlement account have not exceeded its opening balance. Therefore, though obtained at the start of the day, ILF has not been utilized as the balance in its settlement account has been sufficient to cover total debits in most of the day (Chart 1). Only on four days (out of a total of 33 days) total debits did exceed the opening balance. But as some credits to its account were available in the early part of the day, it could have conducted its transactions without ILF.

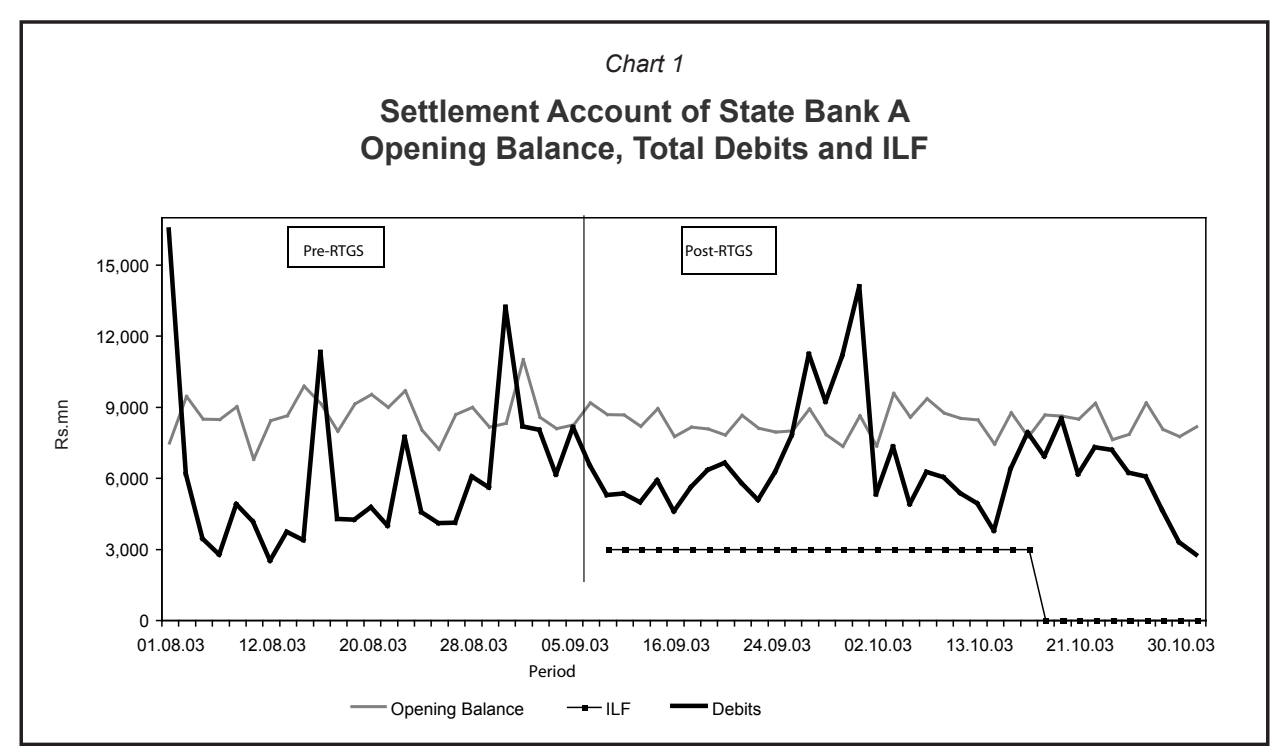

Accordingly, ILF has been obtained only as a precautionary measure and has not been utilized. On the realization of its ability to operate without ILF, the bank has terminated drawing ILF since 16 October 2003. There has not been an observable difference in tota value of debits and credits to its settlement account during the immediately preceding and post RTGS periods.

\section{(ii) Foreign Bank $A$}

Total debits and credits to the settlement account of this foreign bank have always been quite high, around 2-3 times its average reserve balance, indicating the potential need for ILF. Nevertheless, it managed without ILF till 24 September 2003. Between 24 September and
3 October 2003, it had drawn ILF amounting to Rs. 2 billion to 2.9 billion as it had to make relatively large payments on maturing SWAP agreements through which it had generated a relatively large volume of rupee funds. Since 3 October 2003, it has reduced its ILF drawings to Rs.1.25 billion (Chart 2). Total debits to its settlement account during September and October were comparable with those during the pre-RTGS period.

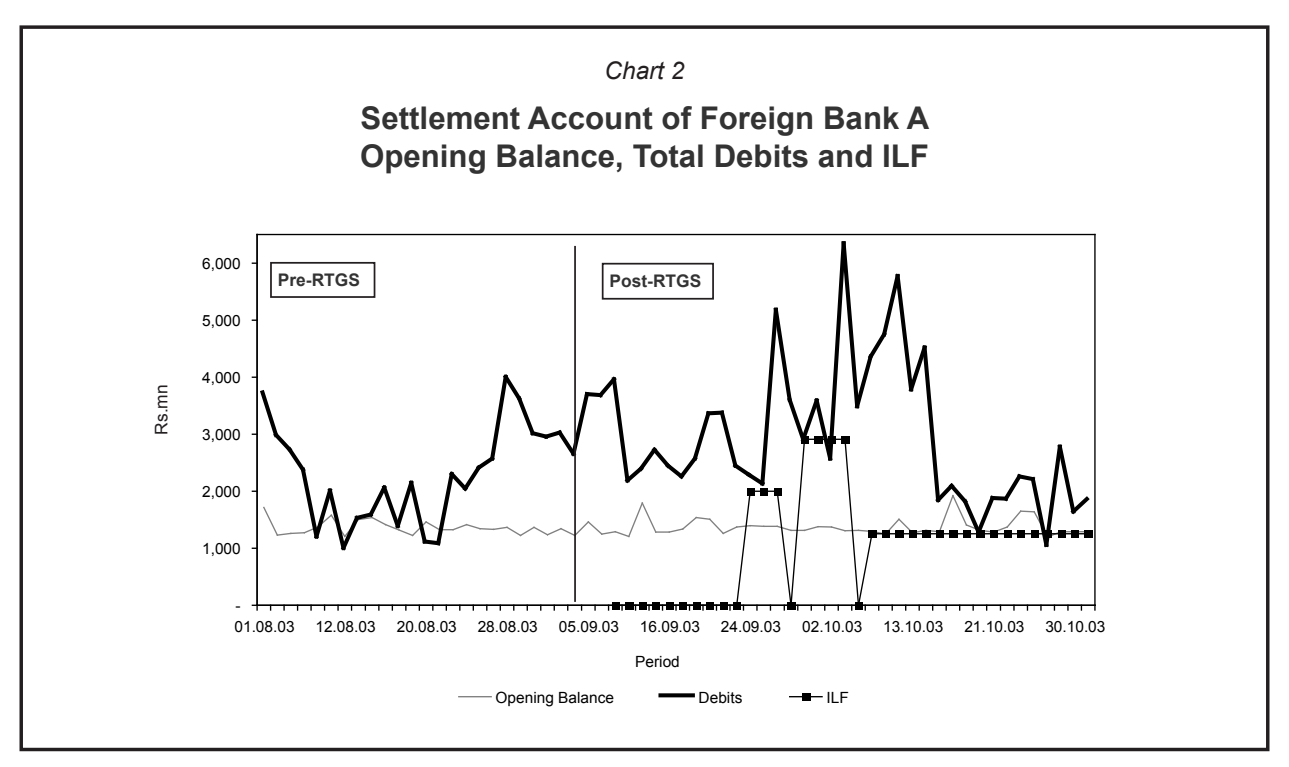

\section{(iii) Domestic Private Bank A}

Inter bank transactions of this domestic private bank have always been quite high with total debits to its settlement account amounting to 5-6 times the average balance in its settlement account. Since the first day of the establishment of RTGS, it has drawn ILF to the value of Rs 1.7 bn. - Rs.2.6 bn. (Chart 3) during the first two months. This drawing has been to cover a single transaction of a licensed specialised bank, the account of which has been with the domestic private bank A. This licensed specialised bank had a funding arrangement (overnight) with another licensed specialised bank which maintains its account with another commercial bank. The lender had insisted that the borrower repays its borrowings first before borrowing again. This created a gridlock situation which was resolved by drawing ILF. This bank subsequently managed to reduce its ILF requirements by breaking the funding arrangement into a number of small loans.

Excluding the debit arising from this funding arrangement, total debits to the settlement account of this bank since the establishment of RTGS has been comparable with those during the pre-RTGS period. 


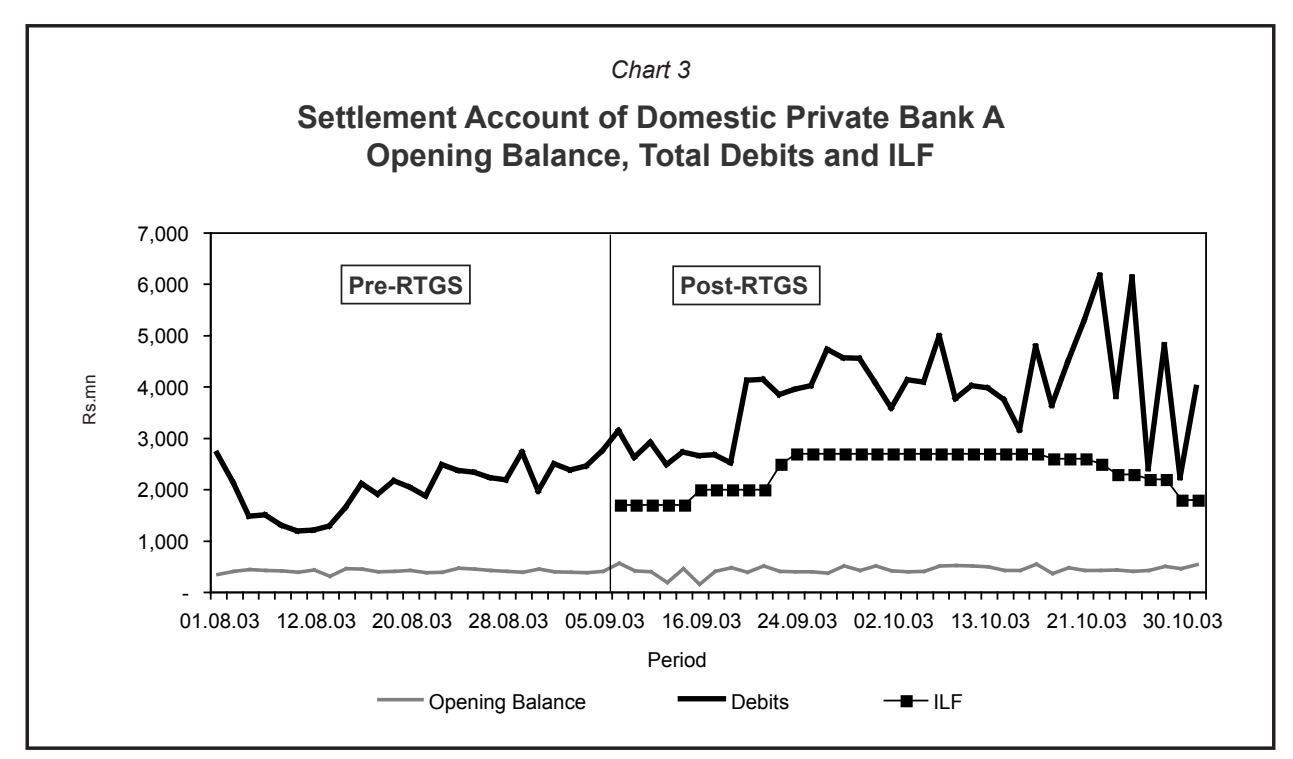

\section{(iv) Domestic Private Bank B}

The volume of transactions handled by this bank has been quite high relative to its deposit base. Total debits to its settlement account has been as high as 6-11 times its opening balance (Chart 4). Accordingly, it was unlikely that it could have operated without ILF. On average total debits to its settlement account in September and October seem to be higher than those during July and August, the pre-RTGS period. However, an increase in debits was observed

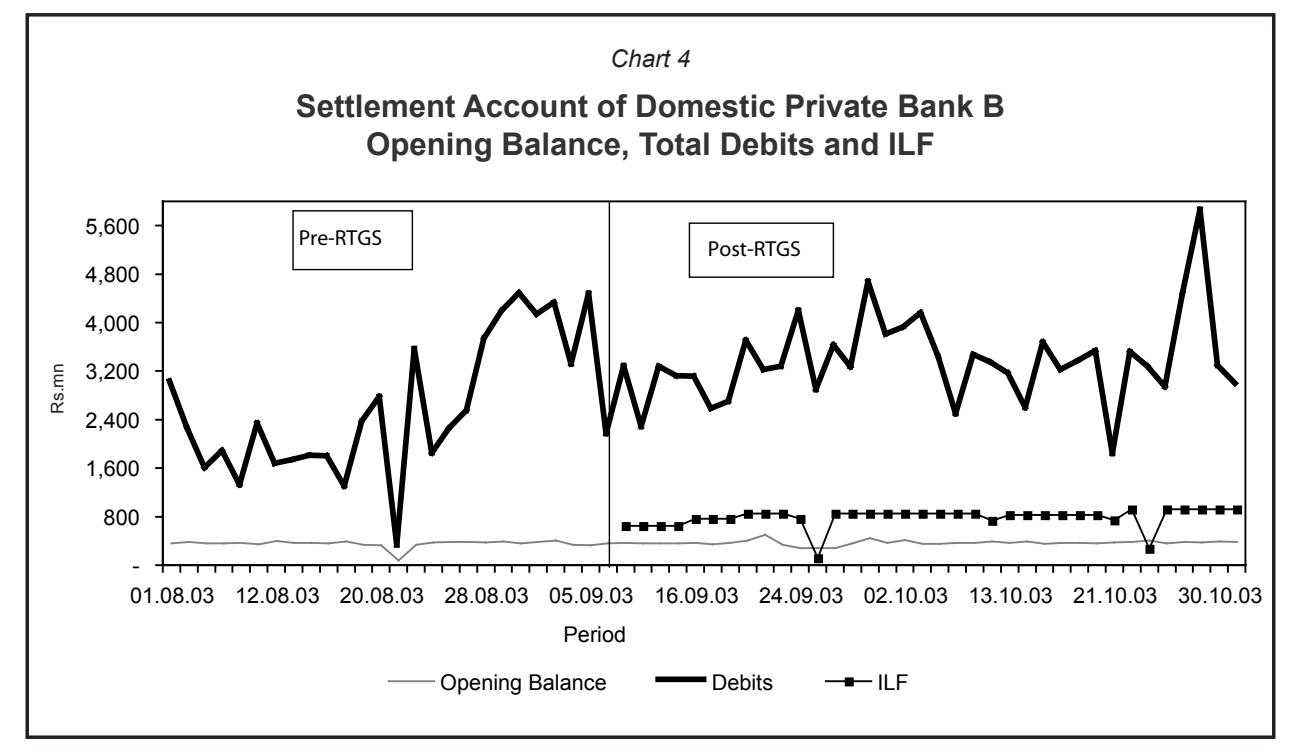

from the latter part of August, which continued into September. Accordingly, the increase in debits cannot be definitely attributed to ILF under RTGS.

\section{(v) Primary Dealers}

The value of debits to each primary dealer's settlement account has been in the range of Rs.0.5 bn. to more than Rs.2.5 bn. Primarily dealers usually maintain a balance closer to zero as they could invest any excess money in overnight repos (Chart $5 \& 6$ ). Therefore,

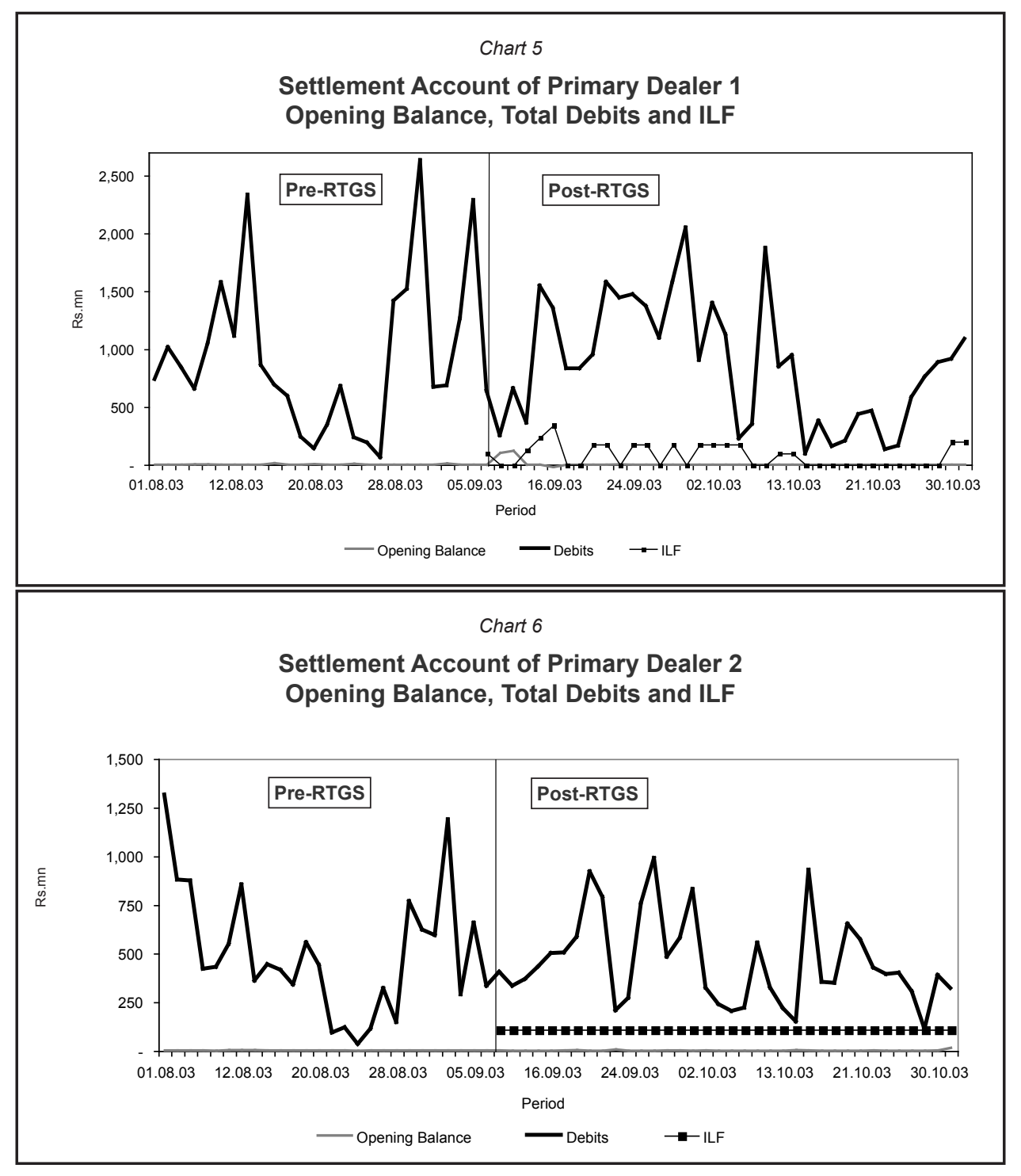


they need ILF for smooth operations. However, their ability to raise ILF is constrained by the lack of securities owned by them as they usually raised funds against their securities. Accordingly, their drawings of ILF have been relatively small ( 8.5 per cent on 31 October 2003) compared with total debits. A significant change has not been observed in total debits after the introduction of ILF.

\section{ILF Drawings and Utilisation}

In the previous section, the focus was on the first two months under the RTGS, so as to examine whether ILF drawings were comparable with the implicit ILF during immediately preceding months. This section examines ILF drawings and their utilization during the entire period from September 2003 to the end December 2004 (Chart 7) with a view to identifying whether there had been an excessive use of ILF by participating institutions.

Until the scripless securities settlement system was established on 2 February 2004, the provision of ILF was against securities in scrip form through a cumbersome procedure, which involved participants endorsing each security in favour of the Central Bank and handing over them to the Central Bank as well as gather them, re-endorsed by the Central Bank whenever, they wish to gain the ownership of securities, after returning ILF. In view of this and the fact that the system was new and participants did not want to face the risk of not having sufficient volume of liquidity to meet payment obligations on real time, relatively a large volume of ILF was drawn at the early stage. In September 2003, the average drawings were around Rs.8.4 billion per day.

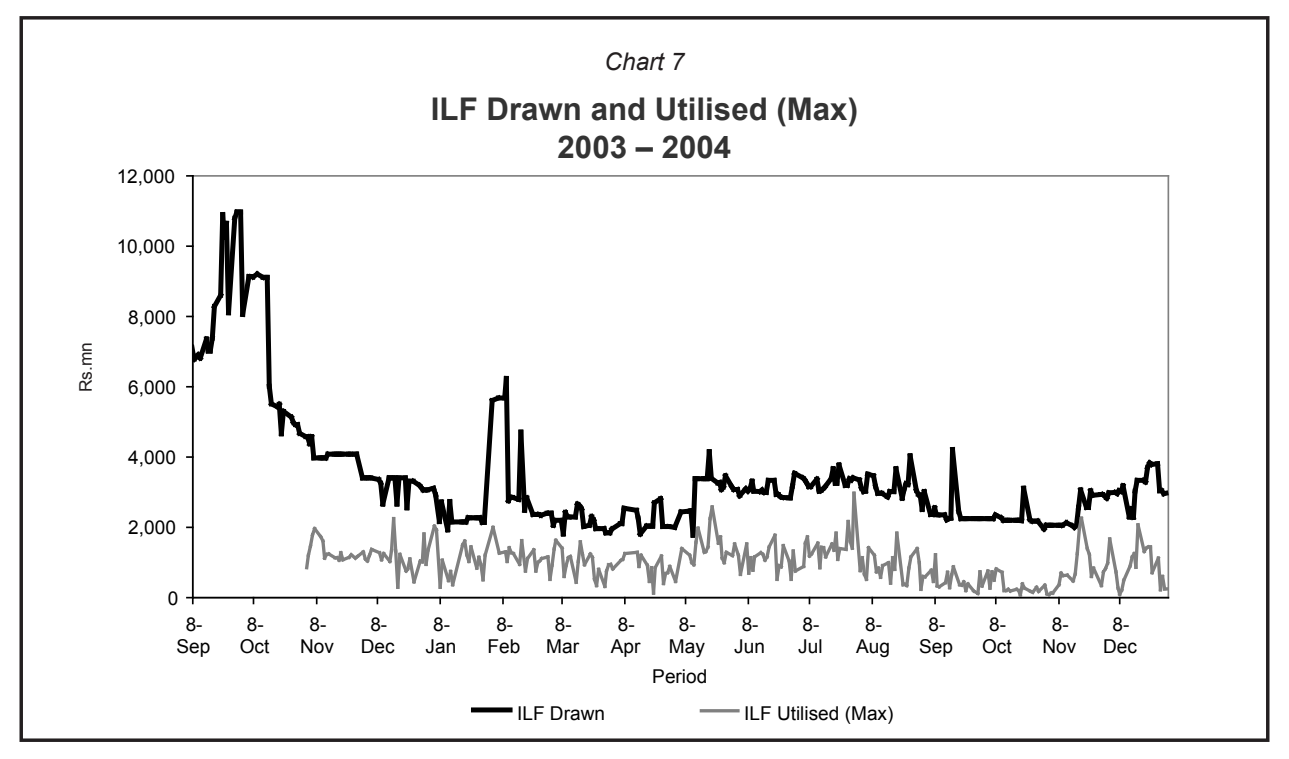

However, with the participants gaining experience, ILF drawings declined to Rs.3.2 bn per day, on average in December 2003. The actual utilization was even lower around 35 per cent (Rs.1 bn) in December 2003. The balance remained unutilized in the participants settlement account at the Central Bank.

Once again in February 2004, there was a sharp increase in ILF as participants drew a large volume of ILF as a precautionary measure to face any unforeseen development with the establishment of a scripless securities settlement system. However, the actual utilization remained relatively low around its normal level. During the year as a whole, ILF drawings were around Rs.2.7 billion per day on average but fluctuated with a standard deviation of Rs.0.6 billion. The actual utilization was about 33 per cent of the drawings, and amounted to Rs. 0.9 billion per day on average with a standard deviation of Rs. 0.5 billion. The relatively high standard deviation is an indication that participants have not been resorting to heavy use of ILF continuously.

During the year 2004, 14 participants obtained ILF. However, on average, on a day only eight participants have obtained ILF. Out of these average number of participants, five were commercial banks while the balance three were primary dealers. Since the inception of ILF, there had been only two occasions of ILF defaults. The measures in place, including penalty interest at the Bank Rate and the suspension of the facility for repeated defaults have ensured the prompt reversal of ILF before the close of Lankasettle on each business day.

\section{ILF and Short term Interest Rates}

Usually central banks implement monetary policy by influencing short term interest rates. One may argue that the provision of ILF free of charge could have an impact on short term interest rates and hence, on the ability of a central bank to implement monetary policy via its control over interest rates. Dale and Rossi (1996) examined this and concluded that as long as official intra day loans have to be repaid at some point during the business day, the terms on which intra day liquidity is provided would not affect a central bank's ability to control short term interest rates. In particular, they emphasized that the provision of intra day liquidity free of charge and in unlimited quantity by the Bank of England in the United Kingdom RTGS System would not impair the Bank's control on short term interest rates. This conclusion is equally valid in the case of Sri Lanka as well, as there is a strict restriction that ILF should be repaid within the business day and hence, it is impossible for a bank or a primary dealer to substitute ILF for an overnight facility without facing severe penalties. Accordingly, the market for intra day liquidity is completely separated from the market for overnight liquidity and the Central Bank could set the terms of ILF independently of the current monetary policy stance. 
However, this segmentation between intra day and overnight loans may not hold strictly if a parallel inter bank market for intra day liquidity emerges, as the restriction preventing the overnight use of intra day liquidity would not hold in the private inter bank market. However, as in the case of England as pointed out in Dale and Rossi (1996), there would be little incentive for an inter bank market for intra day liquidity to emerge, as banks usually hold a sufficient volume of eligible securities to raise ILF from the Central Bank. Though there could be a few participants, in particular some primary dealers who do not have eligible securities in a sufficient volume to raise ILF, their intra day liquidity requirements are unlikely to be large enough to induce a development of a significant market.

As far as the implementation of the monetary policy is concerned, the present practice of providing ILF free of charge in unlimited quantity with strong measures to ensure the reversal within the same business day is quite appropriate, as any other restrictions may provide incentives for an emergence of a private market for intra day liquidity, developments of which may spill over into the overnight market, impacting on the ability of the Bank to control short term interest rates. In this regard it is interesting to note the conclusion of VanHoose (1990) which examined certain proposals for pricing, either explicitly or implicitly, daylight reserve account overdrafts of banks, which is the form in which intra day liquidity is provided by the Federal Reserve System. The paper has demonstrated that the proposals for pricing would have the potential to affect the volatility of 24 hour and longer term interest rates of concern to the Federal Reserve in its role as the monetary authority.

\section{Conclusion}

The paper highlighted the importance of ILF in a RTGS system and examined the impact of ILF on the volume of liquidity available in the financial system. It argued that the volume of liquidity available under the present RTGS system with ILF provided by the Central Bank could not be higher than that available under the end of the day settlement system prevailed in the country. In fact, there is a possibility that it could be even less as ILF is available only against eligible securities whereas, under the end of day settlement system there existed an implicit unrestricted overdraft facility. ILF is provided under stringent conditions with heavy penalties for defaults which ensure that the facility is not converted into an overnight credit. Accordingly, ILF is strictly separated from the market for overnight liquidity and hence, the Central Bank could set terms on ILF independently of the current monetary policy stance. There is no evidence that the availability of ILF has enabled the banks and primary dealers to finance a higher volume of transactions. Accordingly, the release of funds under the ILF is unlikely to create an adverse impact on the conduct of monetary policy as funds flow back to the Central Bank on the same business day.

\section{References}

Central Bank of Sri Lanka, 2003, "System Rules on LankaSettle; Sri Lanka Real Time Gross Settlement and Scripless Securities Depository System” issued to all Commercial banks and primary dealers.

Central Bank of Sri Lanka, 2004, "Operating Instructions on Provision of Intra Day Liquidity Facility (ILF) against Scripless Government Securities on LankaSettle” issued to all Commercial Banks and primary dealers.

Dale, Spencer and Rossi, Marco, 1996, "A Market for Intra-day Funds: Does it have implications for Monetary Policy?”, Bank of England.

VanHoose, David D, 1990, "Bank Behaviour, Interest Rate Determination and Monetary Policy in a Financial System with an Intraday Federal Funds Market", Journal of Banking and Finance Vol. 15 pp.343-365 